\title{
ANALYSIS OF WASTE WATER FOR BIOELECTRIC GENERATION USING MICROBIAL FUEL CELLS
}

\author{
Shweta Rawat ${ }^{1 *}$ and Jyoti Rawat ${ }^{1}$ \\ ${ }^{1}$ Biochemical Engineering Department, B.T. Kumaon Institute of Technology, Dwarahat- 263653, Uttarakhand, India \\ *Corresponding author email: shweta.biotech24@ gmail.com, Contact number: 8057260816
}

\begin{abstract}
Microbial fuel cell technology is a recent approach which consist renewable and sustainable technology for electricity generation. Great attentions have been paid to microbial fuel cells (MFCs). Since, it recovers energy from renewable materials that can be difficult to dispose, such as organic wastes, waste water etc. and utilize variety of biodegradable substrates as fuel. Through which, microorganisms actively catabolize substrate and generate electricity. Besides many advantages, it still faces some limitations such as low power and current density. In the present research waste water was physically, biologically and chemically tested. We found that waste water has less amount of toxicity. Thus, it was assumed as low strength waste water and used for the MFC setup for bioelectric generation.

Initially, the setup was run three times in a small scale. Simultaneously voltage and current was measured at different time intervals. It was observed that in first run, the voltage and current fluctuation data was not significant but voltage generation was varied from 140.8-182.5 $\mathrm{mV}$ in final run, correspondingly current fluctuated from $51-352 \mu \mathrm{A}$ and power varied from 7180.8-66439.1 nW. However, we got highest power density of 0.0215-0.042 $\mathrm{mW}$ when the setup was moved in higher scale.
\end{abstract}

Keywords: Bioelectricity; Microbial Fuel Cell (MFC); Wastewater

\section{Introduction}

India is suffering severe setback due to gradual depletion of non-renewable sources and therefore leading towards an elevated energy crisis. Use of fossil fuels for energy consumption may cause ecological threatened and environmental pollution. Thus, it is necessitate moving towards alternative sources of energy instantly. Microbial Fuel cells (MFCs) are appropriate replacements of traditional fossil fuels devoid of any pollution and can be used as innovative sources of energy. MFCs are promising technology in the direction of electricity production from organic wastes (Rabaey and Verstraete 2005; Logan et al., 2006). It converts energy, available in a bio convertible substrate, directly into electricity. MFCs are kinds of FCs in which microorganisms or enzymes are used as the catalyst to oxidize organic and inorganic matter to generate current and simultaneously this could provide a clean and renewable source of energy. Therefore, "a microbial fuel cell can be defined as a system in which microorganisms function as catalysts to convert chemical energy into electrical energy". Different kinds of waste waters such as sanitary wastes, food processing wastewater, swine waste water and corn Stover contain energy in the form of biodegradable organic matters (Du et al., 2007). It is well known that waste water influent holds a large amount of biomass present in dissolved or suspended forms and energy contents in the form of organics. Moreover, MFCs can remove organic matter to a comparable extent that which is achieved by current waste water treatment plants. Active biocatalyst (microbes) in the anode oxidizes the organic substrates present in waste water and produces electrons and protons (Antonopoulou et al., 2010). The protons are conducted to the cathode chamber through the proton exchange membrane (PEM), and the electrons are conveyed through the external circuit (Rahimnejad et al., 2011). Protons and electrons are reacted in the cathode chamber along with parallel reduction of oxygen to water (Sharma and Li, 2010).

Because of assure sustainable energy generation from different substrates such as organic wastes and waste water etc. research has been intensified in this field in the last few years. It is hard to sum up either MFCs will be implemented on a large scale at treatment plants. It also has some limitations such as, it cannot treat high-strength wastewater 
efficiently and construction cost could be high because of use of cathode catalysts (He et al., 2013), the generated power in MFC is still too low. Since, MFCs are a moderately novel technology. After some more study and research the technique can be executed on a large scale for commercial application.

In our study wastewater of domestic or household origin is mainly treated/used which is basically, does not used in irrigation purpose and left as a waste. Hence, dealing and treatment of waste water can be executed concurrently to complete the present objectives which are analysis of waste water and bioelectricity generation.

\section{Material and Methods}

\section{Sample Collection}

The samples were collected from domestic outlet from B.T. Kumaun Institute of Technology, Dwarahat. Dwarahat is a region of Uttarakhand, India at latitude $29.78^{\circ} \mathrm{N}$ and longitude $79.43^{\circ} \mathrm{E}$ with average elevation of 1,510 metres. Water sample was homogenized and stored in a sterile condition for further analysis.

\section{Biological, Physical and Chemical Analyses of Waste Water}

Biological analysis includes morphological identification and cultural characteristics of microorganisms. Different physical analyses such as $\mathrm{pH}$, temperature, hardness, total solids and filterable solids were tested. Whereas, chemical tests includes chloride test, alkalinity test, fluoride test, nitrate test, iron test, chlorine (residual) test, copper, lead which was done by Standard methods for the examination of water and waste water by American public health association (APHA, 1998).

\section{Experimental Setup for Bioelectricity Generation from Waste Water}

\section{Materials}

A single chambered MFC (SC MFC) was designed in the laboratory which consist of membrane, the purpose of the membrane is to keep anode and cathode solutions separated by allowing ion transfer. Nafion is used as cation exchange membrane (CEM) to allow the passage for the ion exchange. While, partitioning the anode chamber and the cathode chamber a salt bridge was prepared by using agarose gel, salt and water. Other materials for MFC includes copper wires, electronic multi meter, aquarium pump (or other substitutes for aeration), tubings, Ni epoxy and PVC pipes.

\section{Salt Bridge}

This salt bridge was designed by taking PVC pipes of 1 inch diameter, poured with agar and salt solution. After refrigeration of half an hour, it was ready for use as proton exchange membrane (PEM).

\section{Anode}

Electrodes were prepared by taking copper wires of 18 inches length and $2 \mathrm{~mm}$ diameter. For building anode we have used $6 \times 6$ inches of wire meshed with small copper wires. This anode was finally immersed in our waste water sample and cathode was exposed to the air. A $1000 \mathrm{~mL}$ beaker was used as an anode chamber poured with wastewater sample. This chamber was exposed to the anaerobic condition with the help of sealing it with aluminium foil.

\section{Cathode}

Same size beaker was used for preparation of cathode chamber $(1000 \mathrm{~mL})$ which was poured with brine solution $(30 \mathrm{~g} / \mathrm{L}$ and $70 \mathrm{~g} / \mathrm{L})$. The electrode which is meshingless is dipped into the solution and the other end is exposed to the open air (Fig.1). Same designing method was further used for our final model of MFC. The internal wiring of anode and cathode was connected to a multimeter to complete the circuit. The entire setup was left for 30 minutes for stabilization and the deflection in the multimeter was noted down in every reading.

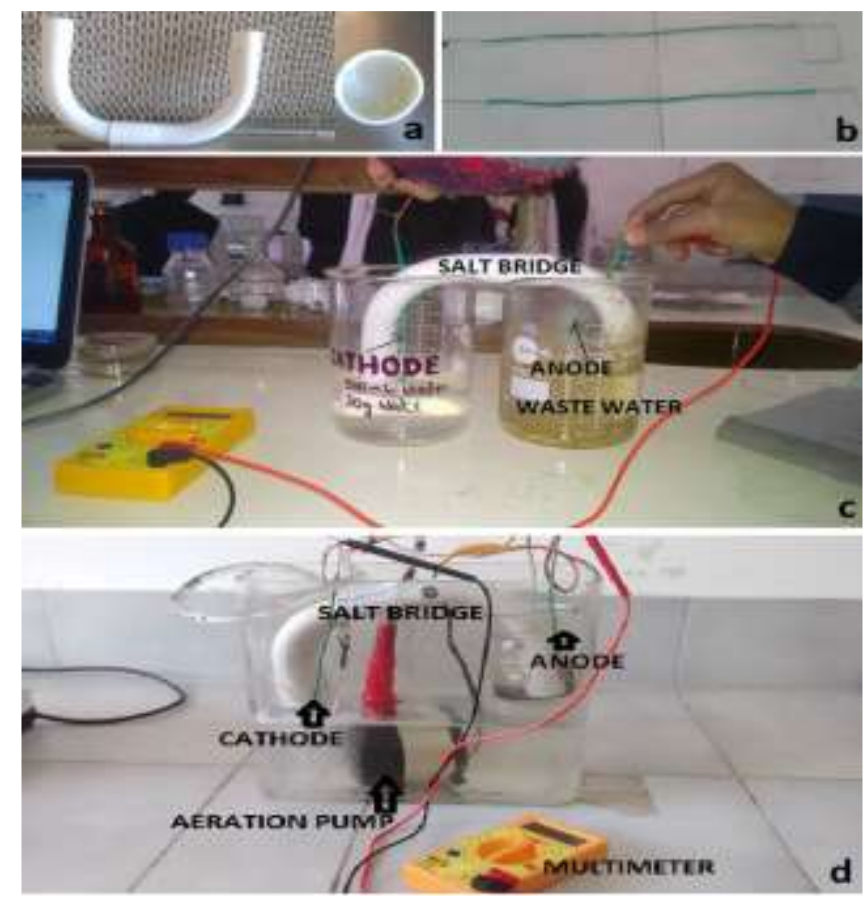

Fig. 1: a. Salt bridge b. Anode/Cathode design c. Experimental Setup double chamber d. Experimental setup single chamber with anode chamber within cathode chamber

\section{Results and Discussion}

By using the APHA standard protocol biological, physical and chemical analyses was done. Primarily, biological examination was attempted and gram positive bacterial colonization was observed in the petri dishes. Further, microscopic examination revealed that the average 30 colonies were observed and all the colonies were in coccus shape (Table 1). 
Through physical analysis we noticed that waste water sample was hard in nature with 5.8-6 $\mathrm{pH}$ and has less total and filterable solids. The temperature measured was $19.8^{\circ} \mathrm{C}$ (Table 2).

Table 1: Biological examination of waste water

\begin{tabular}{|l|l|l|l|}
\hline Sample & $\begin{array}{l}\text { Number } \\
\text { of } \\
\text { Colonies }\end{array}$ & Morphological & $\begin{array}{l}\text { Gram } \\
\text { staining }\end{array}$ \\
\hline $\begin{array}{l}\text { Waste } \\
\text { water } \\
\text { sample }\end{array}$ & 30 & $\begin{array}{l}\text { Small, Spherical, } \\
\text { Circular, Yellow and } \\
\text { Orange }\end{array}$ & $\begin{array}{l}\text { Retained } \\
\text { dark } \\
\text { purple }\end{array}$ \\
\hline
\end{tabular}

Table 2: Physical parameters of waste water

\begin{tabular}{|l|l|l|}
\hline Sample & Parameters & Results \\
\hline Waste water sample & & \\
(B.T.K.I.T, Dwarahat) & $\mathrm{pH}$ & 5.8 \\
\cline { 2 - 3 } & Temperature & 19.8 \\
\cline { 2 - 3 } & Hardness & 10 \\
\cline { 2 - 3 } & Total solid & 0.059 \\
\cline { 2 - 3 } & Filterable & 0.768 \\
\cline { 2 - 3 } & solid & \\
\hline
\end{tabular}

Table 3 depicted that the metal concentration in the collected sample reported for copper, potassium, lead, fluoride and chloride was $0.174 \mathrm{mg} / \mathrm{L}, 0.196 \mathrm{mg} / \mathrm{L}, 0.161$ $\mathrm{mg} / \mathrm{L}, 0.5 \mathrm{mg} / \mathrm{L}$ and $100 \mathrm{mg} / \mathrm{L}$ respectively. However, free chlorine was negligible. According to Indian standard and WHO guideline the desirable concentrations for copper 1.0 $\mathrm{mg} / \mathrm{L}$, lead $0.05 \mathrm{mg} / \mathrm{L}$, fluoride $1.0 \mathrm{mg} / \mathrm{L}$ and chloride 250 $\mathrm{mg} / \mathrm{L}$. so it was observed that lead concentration was higher than allowable limit, however copper, fluoride and chloride concentration were less than standard values. Hence, it appears that waste water used in MFC holds low strength. It has been reported in He, et al. (2013) study that MFCs cannot efficiently treat high strength waste water.

At different time intervals the measurement of voltage was performed using a digital multimeter. The current and power was calculated by using the following equations. $\mathrm{i}=\mathrm{V} / \mathrm{R}$ and $\mathrm{P}=\mathrm{iV}$, where $\mathrm{i}=$ current and $\mathrm{V}=$ voltage, $\mathrm{R}=$ resistance and $\mathrm{P}=$ power. The process performance was recorded for two hours' time duration. For three different test runs, it was observed that in first two, the voltage and current fluctuation data was not significant but in last one the voltage generation was varied, from 140.8-182.5 (mV), correspondingly current fluctuated from 51-352 $\mu \mathrm{A}$ (Table 4-6). As a result power varied from 7180.8-66439.1 nW (Table 7). These three runs were compared by plotting voltage/current fluctuation curve against time (Fig. 2-5).

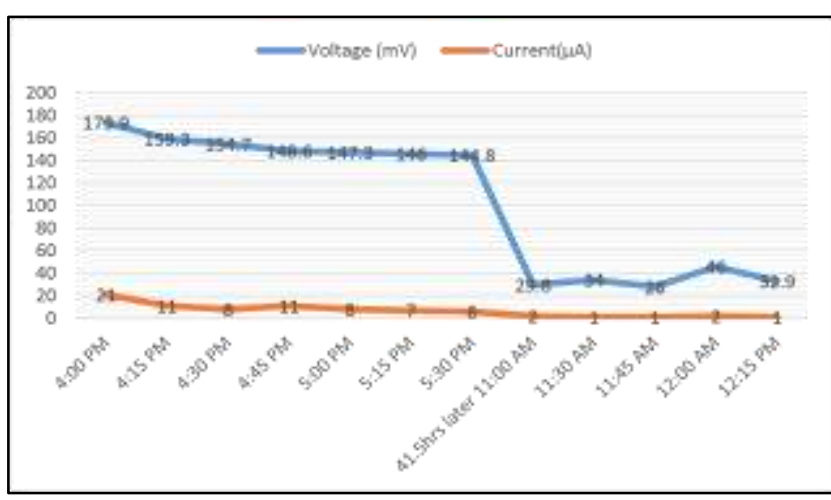

Fig. 2: Plot between current/voltage and time when anode chamber is filled with domestic waste water and cathode chamber with brine solution having concentration $30 \mathrm{~g} / \mathrm{L}$

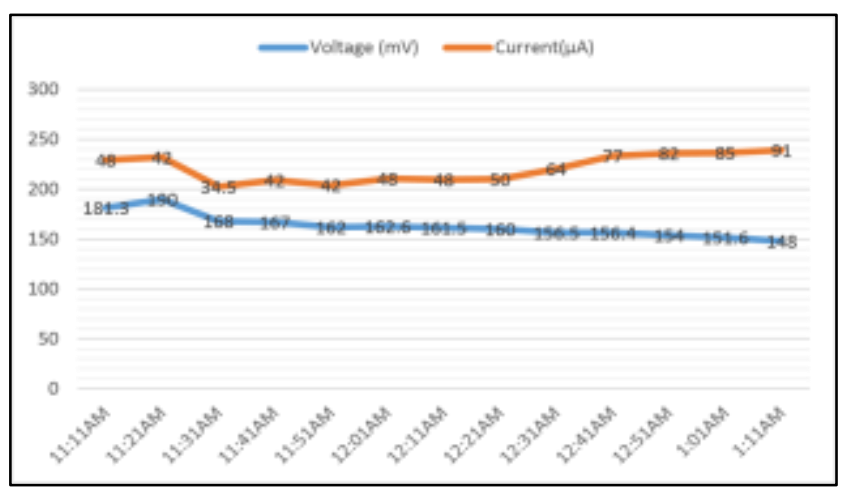

Fig. 3: Plot between current/voltage and time when anode chamber filled with domestic waste water and appropriate aeration and cathode chamber with brine solution having concentration $30 \mathrm{~g} / \mathrm{L}$

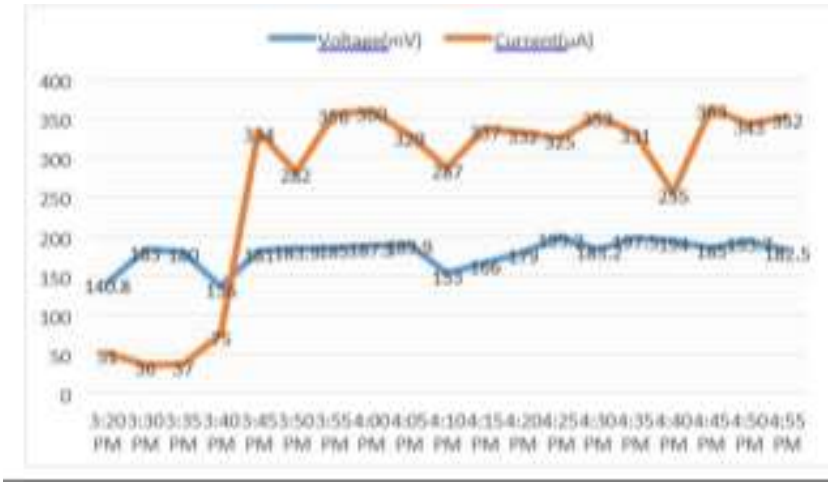

Fig. 4: Plot between current/voltage and time when anode chamber filled with domestic waste water and appropriate aeration and cathode chamber with brine solution having concentration $75 \mathrm{~g} / \mathrm{L}$

To attain good results same experimental setup was designed in higher scale (Fig. 6). The process performance was better in terms of power generation $(0.0215-0.042 \mathrm{~mW})$ (Table 8 and Fig. 7). This result indicates that the movement of protons was faster, so the voltage and current generation was more. 
Table 3: Chemical examination of waste water

\begin{tabular}{|l|l|l|l|l|l|l|l|l|}
\hline $\begin{array}{l}\text { Sample } \\
\text { no. }\end{array}$ & $\begin{array}{l}\text { Copper } \\
(\mathrm{mg} / \mathrm{l})\end{array}$ & $\begin{array}{l}\text { Potassium } \\
(\mathrm{mg} / \mathrm{l})\end{array}$ & $\begin{array}{l}\text { Lead } \\
(\mathrm{mg} / \mathrm{l})\end{array}$ & $\begin{array}{l}\text { Fluoride } \\
(\mathrm{mg} /)\end{array}$ & $\begin{array}{l}\text { Chloride } \\
(\mathrm{mg} / \mathrm{l})\end{array}$ & $\begin{array}{l}\text { Chlorine } \\
(\mathrm{mg} / \mathrm{l})\end{array}$ & $\begin{array}{l}\text { Alkalinity } \\
(\mathrm{mg} / \mathrm{l})\end{array}$ & $\begin{array}{l}\text { Iron } \\
(\mathrm{mg} / \mathrm{L})\end{array}$ \\
\hline $\begin{array}{l}\text { Waste } \\
\text { water } \\
\text { sample }\end{array}$ & 0.174 & 0.196 & 0.161 & 0.5 & 100 & 0 & 120 & 0.2 \\
\hline
\end{tabular}

Table 4: Voltage and current values for anode chamber filled with domestic waste water and cathode chamber with brine solution having concentration $30 \mathrm{~g} / \mathrm{L}$

\begin{tabular}{|l|l|l|}
\hline Time & Voltage $(\mathbf{m V})$ & Current $(\boldsymbol{\mu A})$ \\
\hline $4: 00$ PM & 173.9 & 21 \\
\hline $4: 15$ PM & 159.3 & 11 \\
\hline $4: 30$ PM & 154.7 & 8 \\
\hline $4: 45$ PM & 148.6 & 11 \\
\hline $5: 00$ PM & 147.3 & 8 \\
\hline $5: 15$ PM & 146 & 7 \\
\hline $5: 30$ PM & 144.8 & 6 \\
\hline $11: 00$ AM (41.5hrs later) & 29.8 & 2 \\
\hline $11: 30$ AM & 34 & 1 \\
\hline $11: 45$ AM & 28 & 1 \\
\hline $12: 00$ AM & 46 & 2 \\
\hline $12: 15$ PM & 32.9 & 1 \\
\hline
\end{tabular}

Table 5: Voltage and current values for anode chamber filled with domestic waste water and cathode chamber with brine solution having concentration $30 \mathrm{~g} / \mathrm{L}$

\begin{tabular}{|l|c|c|}
\hline Time & Voltage $(\mathrm{mV})$ & Current $(\mu \mathrm{A})$ \\
\hline $11: 11 \mathrm{AM}$ & 181.3 & 48 \\
\hline $11: 21 \mathrm{AM}$ & 190 & 34.5 \\
\hline $11: 31 \mathrm{AM}$ & 168 & 42 \\
\hline $11: 41 \mathrm{AM}$ & 167 & 42 \\
\hline $11: 51 \mathrm{AM}$ & 162 & 48 \\
\hline $12: 01 \mathrm{AM}$ & 162.6 & 48 \\
\hline $12: 11 \mathrm{AM}$ & 161.5 & 50 \\
\hline $12: 21 \mathrm{AM}$ & 160 & 64 \\
\hline $12: 31 \mathrm{AM}$ & 156.5 & 77 \\
\hline $12: 41 \mathrm{AM}$ & 156.4 & 82 \\
\hline $12: 51 \mathrm{AM}$ & 154 & 85 \\
\hline $1: 01 \mathrm{AM}$ & 151.6 & 91 \\
\hline $1: 11 \mathrm{AM}$ & 148 & 8 \\
\hline after $72 \mathrm{hrs}$ & 57 & \\
\hline
\end{tabular}


S. Rawat and J. Rawat (2016) Int J Appl Sci Biotechnol, Vol 4(3): 281-287

Table 6: Voltage and current values for anode chamber filled with domestic waste water and cathode chamber with brine solution having concentration $75 \mathrm{~g} / \mathrm{L}$

\begin{tabular}{|l|l|l|}
\hline Time & Voltage $(\mathbf{m V})$ & Current $(\boldsymbol{\mu} \mathbf{A})$ \\
\hline $3: 20$ PM & 140.8 & 36 \\
\hline $3: 30$ PM & 183 & 37 \\
\hline $3: 35$ PM & 180 & 75 \\
\hline $3: 40$ PM & 136 & 334 \\
\hline $3: 45$ PM & 181 & 282 \\
\hline $3: 50$ PM & 183.9 & 356 \\
\hline $3: 55$ PM & 185 & 360 \\
\hline $4: 00$ PM & 187.5 & 329 \\
\hline $4: 05$ PM & 189.9 & 287 \\
\hline $4: 10$ PM & 153 & 337 \\
\hline $4: 15$ PM & 166 & 332 \\
\hline $4: 20$ PM & 179 & 325 \\
\hline $4: 25$ PM & 199.2 & 353 \\
\hline $4: 30$ PM & 183.2 & 331 \\
\hline $4: 35$ PM & 197.5 & 255 \\
\hline $4: 40$ PM & 194 & 363 \\
\hline $4: 45$ PM & 185 & 343 \\
\hline $4: 50$ PM & 193.7 & 352 \\
\hline $4: 55$ PM & 182.5 & \\
\hline
\end{tabular}

Table 7: Data related to Power (nW) of three different experimental setups shown above

\begin{tabular}{|l|l|l|l|}
\hline Time (15 minutes gap) & Power & Power & Power \\
\hline & 1 & 2 & 3 \\
\hline 1 & 3651.9 & 7804.8 & 7180.8 \\
\hline 2 & 1752 & 7752 & 6660 \\
\hline 3 & 1237 & 8000 & 51859 \\
\hline 4 & 1634.6 & 8451 & 62477.1 \\
\hline 5 & 1178.4 & 11104.4 & 59428 \\
\hline 6 & 1022 & 12628 & 65372.5 \\
\hline 7 & 868.8 & 12886 & 66439.1 \\
\hline
\end{tabular}

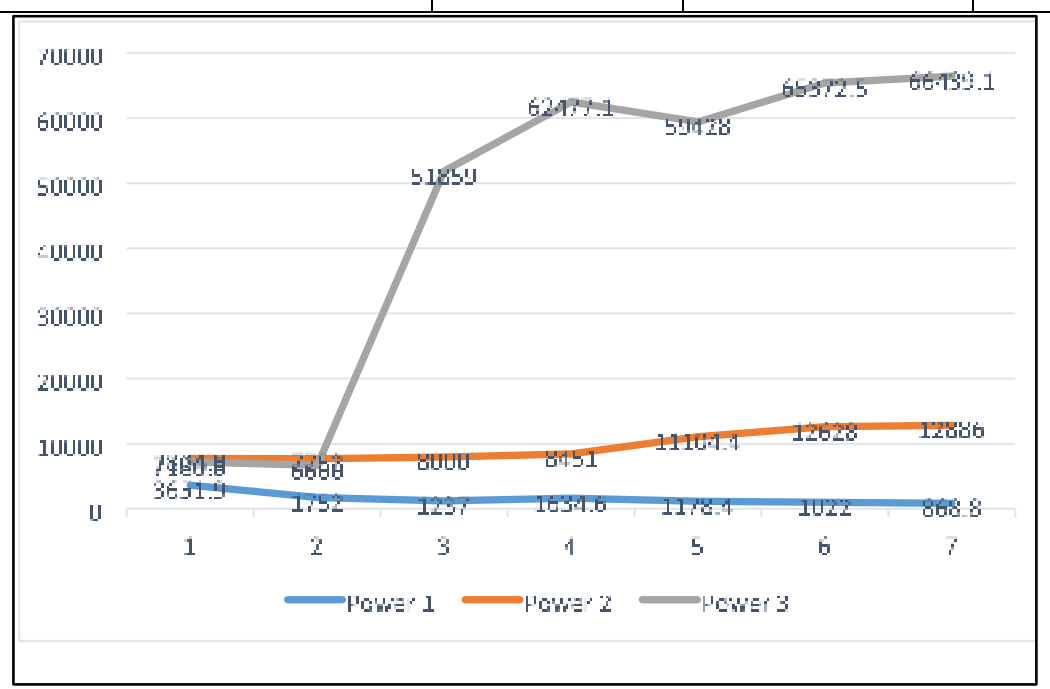

Fig. 5: Graphical representation of data corresponding to Power (nW) of three different experimental setups shown above 


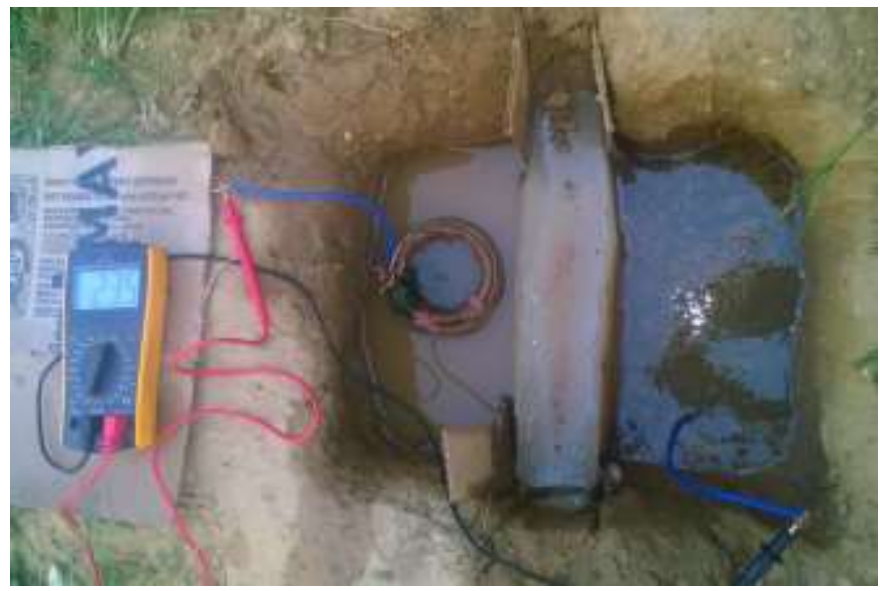

Fig. 6: Final model of microbial fuel cell at higher scale

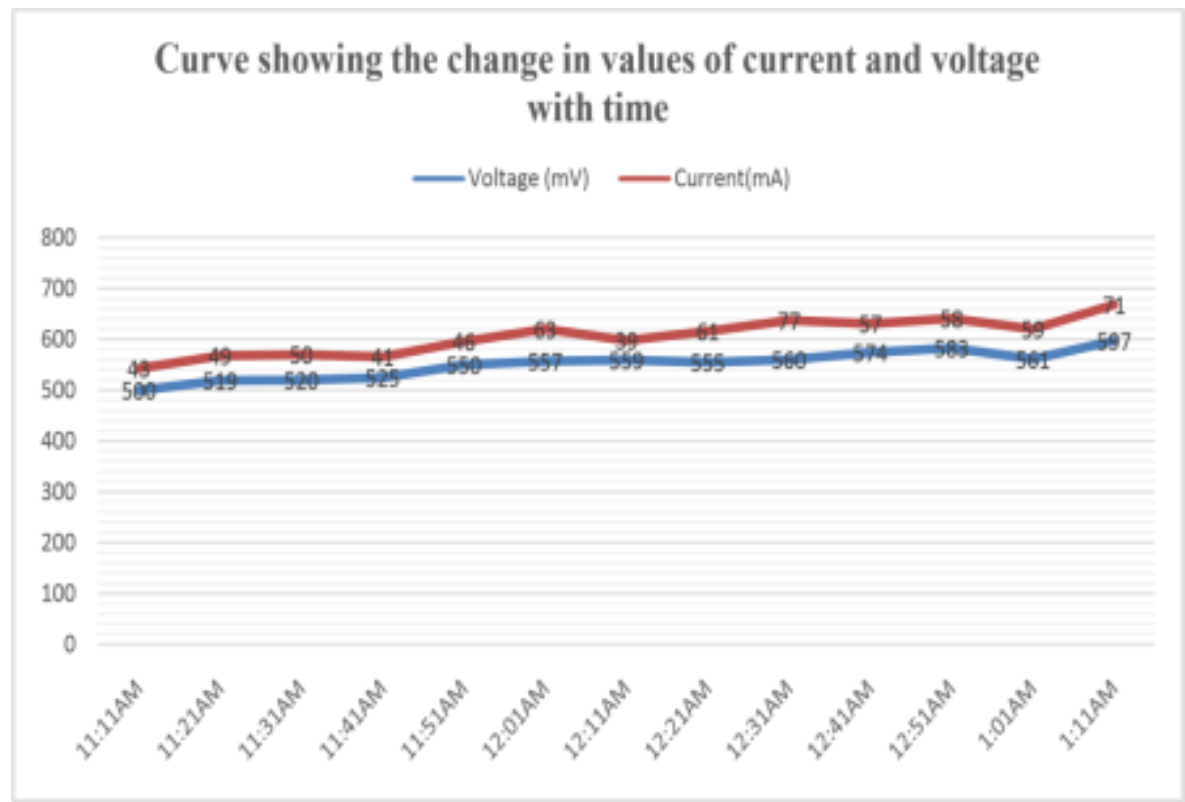

Fig. 7: Graphical representation of data corresponding change in values of current and voltage with time.

Table 8: Voltage, current and power values at higher scale

\begin{tabular}{|l|l|l|l|}
\hline Time & Voltage $(\mathrm{mV})$ & Current (mA) & Power (W) \\
\hline $11: 11 \mathrm{AM}$ & 500 & 43 & .021500 \\
\hline $11: 21 \mathrm{AM}$ & 519 & 49 & .025431 \\
\hline $11: 31 \mathrm{AM}$ & 520 & 50 & .026000 \\
\hline $11: 41 \mathrm{AM}$ & 525 & 41 & .021525 \\
\hline $11: 51 \mathrm{AM}$ & 550 & 46 & .025300 \\
\hline $12: 01 \mathrm{AM}$ & 557 & 39 & .035091 \\
\hline $12: 11 \mathrm{AM}$ & 559 & 61 & .021801 \\
\hline $12: 21 \mathrm{AM}$ & 555 & 77 & .033855 \\
\hline $12: 31 \mathrm{AM}$ & 560 & 57 & .042350 \\
\hline $12: 41 \mathrm{AM}$ & 574 & 58 & .032718 \\
\hline $12: 51 \mathrm{AM}$ & 583 & 59 & .033814 \\
\hline $1: 01 \mathrm{AM}$ & 561 & 597 & .033099 \\
\hline $1: 11 \mathrm{AM}$ & & 51 & .042387 \\
\hline
\end{tabular}




\section{Conclusion}

Microbial fuel cells provide sustainable energy generation in the coming future. MFC is a good alternative energy resource and a promising technology that can be coupled with a wastewater treatment system and reduction of environmental load. Present study is a straight forward initiative and simple approach to utilize waste water as a substrate for bioelectric generation using MFC.

\section{Acknowledgement}

Mr. Rahul Kandpal is greatly acknowledged to help in MFC setup.

\section{References}

American Public Health Association, APHA (1998) Standard methods for the examination of water and wastelwater, 20th ed. New York.

Antonopoulou G, Stamatelatou K, Bebelis S and Lyberatos G (2010) Electricity generation from synthetic substrates and cheese whey using a two chamber microbial fuel cell. Biochem. Eng. 50: 10-15.
Du Z, Li H and Gu TA (2007) State of the art review on microbial fuel cells: a promising technology for wastewater treatment and bioenergy. Biotechnol. Adv. 25: 464-482.

He Z, Zhang F and Ge Z (2013) Using microbial fuel cells to treat raw sludge and primary effluent for bioelectricity generation: Final report. Microb. Fuel Cell Tech. 1-64.

Logan BE, Hamelers B, Rozendal R, Schroder U, Keller J, Freguia S, Aelterman P, Verstraete W and Rabaey K (2006) Microbial Fuel Cells: Methodology and Technology. Environ. Sci. Tech. 40(17).

Rabaey K and Verstraete W (2005) Microbial fuel cells: novel biotechnology for energy generation. Trends Biotechnol, 23(6): 291-298.

Rahimnejad M, Ghoreyshi AA and Najafpour G (2011) Power generation from organic substrate in batch and continuous flow microbial fuel cell operations. App. Energ. 88: 39994004 .

Sharma Y and Li B (2010) The variation of power generation with organic substrates in single-chamber microbial fuel cells (SCMFCs). Biores. Technol. 101: 1844-1850. 